\title{
In Memoriam Robert B. Seidman
}

\author{
Maureen A. O’Rourke*
}

\begin{abstract}
From 1974 until 2013, Boston University School of Law was enriched by the presence of Professor Robert Seidman and his wife and academic partner Ann. Bob worked until the age of 93 and passed away shortly after retiring from what was a truly extraordinary career.
\end{abstract}

From 1974 until 2013, Boston University School of Law was enriched by the presence of Professor Robert Seidman and his wife and academic partner Ann. Bob worked until the age of 93 and passed away shortly after retiring from what was a truly extraordinary career. He was a great colleague and friend and I admired him tremendously and miss him.

Bob graduated from Harvard College in 1942, just months after the beginning of the Second World War. He joined the United States Coast Guard, thinking that he would be assigned to a quiet light house somewhere on the Great Lakes. Instead, he was seconded to the US Navy and saw a great deal of action.

He participated in the Arctic convoys that sailed from the United Kingdom, Iceland and North America to northern ports in the Soviet Union - primarily Murmansk. The Royal Navy, Royal Canadian Navy and US Navy escorted about 1,400 merchant ships, which delivered essential supplies to the Soviet Union under the Lend-Lease programme, including tanks, fighter planes, fuel, ammunition, raw materials and food.

In September 1944, with the rank of Lieutenant, Bob was given command of Landing Ship/Tank 767 (LST-767). Crews irreverently called these ships 'Large, Slow Targets', but they were the vessels that put troops and heavy supplies on enemy shores, often during the heat of battle.

Bob captained the LST-767 during the 82-day-long Battle of Okinawa, the largest amphibious assault during the Pacific War. He landed his ship on Okinawa on the second day of the invasion and off-loaded the landing crafts and troops sent from Pearl Harbor. He continued to command LST-767 through the surrender of Japan and into the subsequent occupation. For his service, Bob earned the Coast Guard's Commendation Ribbon.

After the War, Bob returned home to study law at Columbia Law School, and more importantly, to marry the love of his life Ann. Ann's brother had been Bob's roommate in college, and Bob spent quite a bit of time sailing with Ann's family off the coast of Maine. During this time Bob and Ann started a relationship that

* Professor of Law and Michaels Faculty Research Scholar. Prof O'Rourke has been the Dean of Boston University School of Law since 2006. 
lasted for the next 70-plus years. Bob earned a law degree and Ann earned a PhD in economics. Together they raised five children, sailed, co-authored articles and books, co-taught classes, travelled the world and shared a very messy and cluttered office near mine in the BU Law Tower.

After graduating from Columbia Law, Bob spent several years practising law in Connecticut and New York, but he found the work unsatisfying. In 1962 the Ford Foundation recruited Bob and Ann go to Ghana to help the new government develop post-colonial institutions.

This move began Bob and Ann's lifelong work with Africa, law and development, social justice for those left behind by colonialism, and legislative drafting. These subjects became inseparable for the Seidmans; thoughtful and well-drafted legislation was essential to changing the status quo and removing the barriers to a more just and equitable society. Over the years they created the Institutional Legislative Theory and Methodology (ILTAM), which demanded that government officials and legislative drafters not just address surface problems, but to change the behaviour of people and institutions that caused social problems. Their insights and tireless teaching made Bob and Ann pioneers in the field of Law and Development.

After teaching at the University of Ghana, Ann and Bob went on to teach law and development at the University of Lagos in Nigeria, the University of Dar es Salaam in Tanzania, the University of Zambia and the University of Zimbabwe. During the tumultuous times of Africa in the 1960s, Bob and his ideas were, at times, labelled dangerous to the ruling government. His stories of leaving a country a step ahead of the authorities or being the target of protests were always entertaining - but also showed the power and high stakes of his work.

Bob came to Boston University School of Law in 1974 and was a cherished professor and colleague until his retirement in 2013. He founded the School's Legislative Services Program where he supervised externs working with the Massachusetts Legislature and trained legislative drafters in the Legislative Policy and Drafting Clinic. Over the years he and Ann taught literally thousands of students and inspired them to use their legal training for social change and a more equitable society.

Bob and Ann meant a great deal to the institution that is Boston University and particularly to its law school. Their impact was outsized - reaching far beyond the borders of BU and the legal academy generally to legislative drafters around the world. They taught short courses in law and development and legislative drafting around the world. The students would be drafters, ministry officials and legislators, who learned by drafting and assessing bills according to the Seidmans' methodology. They worked on agricultural policy and banking reform in China, child labour laws in Nepal, rural road maintenance and health programmes in Sri Lanka, agricultural cooperatives in Bhutan, and restructuring provincial welfare and health systems in South Africa. In 1988-1989, Bob was a Fulbright professor of law at Beijing University.

Bob and Ann also hosted many people from around the world at BU with the ultimate goal of training drafters and legislators so that they could return to their own countries with the skills to train others. In 2000, the Seidmans collaborated 
with a former student in Sri Lanka to write Legislative Drafting for Democratic Social Change: A Manual for Drafters, which became a guide for untold number of drafters around the world. It has been translated into many languages including Chinese, Russian, Bahasa Indonesian, Sinhalese, Vietnamese and Macedonian. In fact, the week Bob passed away I received an email from the United Nations Development Programme in Lao asking if we could send the Seidmans' handbook to them as a reference as they conduct an assessment on the law-making process there. From their office at BU, they also contributed to constitutional drafting in Namibia, Somalia, Iraq and Afghanistan.

The global reach of their work was amazing. He and Ann brought the BU Law name and spirit to the furthest reaches of the Earth, enhancing our reputation in the process. Very often when we seek relationships around the world, other schools know us and regard us with respect and esteem because they knew and worked with Bob and Ann.

While my goal here is to speak on behalf of the BU Law, I'd be remiss if I did not add a personal note. Bob and Ann together had a wonderful knack for knowing who among us really needed a hand extended in friendship and, once they offered that hand, it was never withdrawn.

And they did that with me from the minute I joined the faculty and later expanded that to include my husband James. He could not believe their warmth and generosity that by the time he arrived on the scene I took for granted. I can't adequately express my gratitude for all the kindness they have shown me over the years.

They would also share their great passion for sailing and being out in nature. Like many of my colleagues and their families, Ann and Bob invited me and James to their house in Maine. We would spend the day sailing off the coast of Georgetown Island, from Robinhood Cove to the Back River, around Barter's Island and to the Isle of Springs in Booth Bay. If the wind ever died down, Ann and Bob sang sea shanties and folk ballads until the sails filled and they were on their way again. After a day on the water, Bob would build a fire and they would prepare a simple dinner together, with lively discussion and more singing until it was time to sleep.

It was always incredible to me that these people who were literally in the process of changing the world would make time for a younger colleague far outside of their own field of study just because they knew she needed a friend.

So thank you Bob. Thank you for letting me be a small part of a very large life; for teaching me so many things, including, as I have often mentioned to the faculty, the lesson you learned while ferrying convoys during the Second World War - "Don't be bitter!" and most of all for providing us all with the example of what it means to say a life has been well lived.

Godspeed and God bless. 